\title{
HUBUNGAN PEMBERIAN KAPSUL VITAMIN A DENGAN KEJADIAN ISPA \\ PADA ANAK BALITA DI POSYANDU DESA TARUM \\ KECAMATAN PRAJEKAN \\ BONDOWOSO.
}

\author{
Oleh
}

Fika Indah Prastya, Eka suryaningtyas.

\begin{abstract}
Vitamin A adalah vitamin larut lemak yang pertama di temukan. Secara luas, vitamin A marupakan nama generik yang menyatakan semua retinoid dan prekursor/ provitamin A/ karotinoid yang mempunyai aktivitas biologik sebagai retinol (Almeitsier,2010). ISPA merupakan masalah kesehatan yang utama di Indonesia karena masih tingginya angka kejadian ISPA terutama balita. Prevalensi ISPA di Indonesia adalah $25,5 \%$ dengan morbiditas pada bayi $2,2 \%$ dan balita $3 \%$ sedangkan mortalitas pada pada bayi $23,8 \%$ dan balita $15,5 \%$

Penelitian ini penggunakan rancangan penelitian korelasional yang mempelajari tentang Hubungan Pemberian kapsul vitamin A dengan kejadian ISPA, variable dalam penelitian ada dua yaitu variable independen (jkapsul vit A) dan variable dependen (Kejadian ISPA).

Hasil dari pengolahan data di peroleh sebagian besar responden yang memberikan kapsul Vit A cukup baik sebanyak 21 responden (68\%), dari Data riwayat ISPA sebagian besar responden pernah mengalami ISPA sebanyak 22 Responden (71\%), maka di peroleh hasil $\mathrm{p}$ value: $0,000 \mathrm{a}=0,05$ sehinga di simpulkan H1 di terima, artinya adalah hubungan pemberian kapsul Vit A dengan kejadian ISPA
\end{abstract}

Kata Kunci : Kapsul Vit A, ISPA

\section{ABSTRAC}

Vitamin $A$ is the first fat-soluble vitamin found. Broadly speaking, vitamin $A$ is a generic name that states all retinoids and precursors / provitamin $A$ / carotinoids that have biological activity as retinol (Almeitsier, 2010). ISPA is a major health problem in Indonesia because of the high incidence of ARI, especially toddlers. The prevalence of ISPA in Indonesia is $25.5 \%$ with morbidity in infants $2.2 \%$ and toddlers $3 \%$ while mortality in infants $23.8 \%$ and toddlers $15.5 \%$

This study used correlational research design that studied the relationship of Vitamin A capsule with the incidence of ARI, the variable in the study there are two independent variables (jkapsul vit A) and the dependent variable (Genesis ISPA).

The result of data processing obtained by most of the respondents who give VitA capsule is good enough 21 respondents (68\%), from ISPA history most respondents had ISPA of 22 respondents (71\%), then obtained $p$ value: $0,000 a=0$, o5 so that concluded $\mathrm{H} 1$ received, it means the relationship of vitamin A supplementation with the incidence of ISPA

Keywords: Vitamin A, ISPA 


\section{Latar Belakang}

Infeksi pernafasan akut adalah proses inflamasi yang disebabkan oleh virus, bakteri, atipikal (mikoplasma), atau aspirasi subtansi asing yang melibatkan suatu ataw sebagian saluran pernafasan. Saluan pernafasan atas (jalan nafas atas) terdiri dari hidung faring dan laring. Saluran pernafasan bawah terdiri dari bronkus, bronkiolus, dan alveoli(Wong,2004).

ISPA merupakan masalah kesehatan yang penting setiap dua tahun ada dua juta kematian yang disebabkan oleh ISPA. WHO memperkirakan insiden ISPA di negara berkembang 0,29\% (151 juta jiwa). ISPA menempati urutan pertama penyakit yang diderita oleh bayi dan balita di Indonesia. Prevalensi ISPA di Indonesia adalah 25,5\% dengan morbiditas pada bayi $2,2 \%$ dan balita $3 \%$ sedangkan mortalitas pada pada bayi 23,8\% dan balita 15,5\%(Markamah,2012).

Faktor terjadinya ISPA adalah status imuniasi, anak yang tidak mendapat imunisasi mempunyai resiko lebih tinggi daripada yang mendapat imunisasi. Kedua adalah pemberian kapsul vitamin A,vitamin A meningkatkan imunitas anak, anak ataw bayi yang tidak mendapat vitamin A, beresiko lebih besar terkena penyakit ISPA (Marni,2014). Oleh sebab itu pemberian kapsul vitamin A baik untuk pencegahan ISPA.

Berdasarkan hasil rekam medik di Posyandu Desa Tarum Kecamatan Prajekan Bondowoso pada tahun 2013 iniden ISPA sebanyak 113 pada anak balita. Pada tanggal 15 November 2014 setelah dilakukan wawancara pada 10 orang ibu yang mempunyai anak balita, diperoleh 8 anak $(80 \%)$ yang pernah mengalami ISPA, 2 anak ( 20\%) yang tidak pernah ISPA.

Berdasarkan data yang di dapat dan pentingnya pemberian vitamin A pada balita untuk mencegah ISPA maka peneliti tertarik untuk meneliti hubungan pemberian vitamin A demgan kejadian ISPA pada balita di Posyandu Desa Tarum Kecamatan Pajekan Bondowoso.

\section{Metode Penelitian}

Desain penelitian adalah sesuatu yang sangat penting dalam penelitian, memungkinkan pengontrolan maksimal beberapa faktor yang dapat mempengaruhi akurasi suatu hasil (Nursalam,2011). Penelitian ini penggunakan rancangan penelitian korelasional yang mempelajari tentang Hubungan Pemberian kapsul vitamin A dengan kejadian ISPA

\section{Hasil Penelitian}

\section{Data Umum}

\section{Gambaran Umum Tempat Penelitian}

Lokasi yang dijadikan tempat penelitian adalah di Posyandu desa Tarum Kecamatan Prajekan Bondowoso, terdiri dari 2 RT batas wilayah sebelah barat adalah persawahan,sebelah timur berbatasan dengan Sungai,sebelah utara berbatasan dengan Desa,

\section{Data Identitas Responden Berdasarkan Umur}

Distribusi Frekuensi Responden Berdasarkan Umur balita di Desa Tarum Kecamatan Prajekan Bondowoso

\begin{tabular}{|l|c|c|c|}
\hline No & Umur(tahun) & Frekuensi(f) & Prosentase(\%) \\
\hline 1 & 1 & 3 & 10 \\
3 & 2 & 10 & 32 \\
4 & 3 & 10 & 32 \\
5 & 4 & 6 & 19 \\
\hline \multicolumn{2}{|c|}{ Jumlah } & 31 & 7 \\
\hline
\end{tabular}

Berdasarkan data pada tabel di atas dapat diketahui bahwa responden yang berusia 2 dan 3 tahun di di Posyandu 
desa Tarum Kecamatan Prajekan Bondowoso sebanyak 10 responden(32\%).

Data Identitas Responden Berdasarkan Jenis Kelamin

Distribusi Frekuensi Responden Berdasarkan Jenis Kelamin Balita di Desa Tarum Kecamatan Prajekan Bondowoso.

\begin{tabular}{|l|l|c|c|}
\hline $\begin{array}{l}\text { N } \\
\text { o }\end{array}$ & $\begin{array}{l}\text { Jenis } \\
\text { Kelamin }\end{array}$ & $\begin{array}{l}\text { Frekuensi } \\
\text { (f) }\end{array}$ & $\begin{array}{l}\text { Prosentase( } \\
\text { \%) }\end{array}$ \\
\hline 1 & $\begin{array}{l}\text { Laki- } \\
\text { Laki }\end{array}$ & 22 & 71 \\
2 & $\begin{array}{l}\text { Perempu } \\
\text { an }\end{array}$ & 9 & 29 \\
\hline \multicolumn{2}{|c|}{ Jumlah } & 31 & 100 \\
\hline
\end{tabular}

Berdasarkan data label di atas dapat diketahui bahwa responden yang berjenis kelamin laki laki di Desa Tarum Kecamatan Prajekan Bondowoso sebanyak 22 responden $(71 \%)$.

\section{Data Pemberian kapsul Vit A}

Distribusi Frekuensi Responden Berdasarkan Pemberian kapsul Vit Adi Desa Tarum Kecamatan Prajekan Bondowoso.

\begin{tabular}{|c|c|c|c|}
\hline $\begin{array}{l}\mathbf{N} \\
\mathbf{0}\end{array}$ & $\begin{array}{l}\text { Faktor } \\
\text { Lingkung } \\
\text { an }\end{array}$ & $\begin{array}{l}\text { Frekuensi } \\
\text { (f) }\end{array}$ & $\begin{array}{l}\text { Prosentase( } \\
\%)\end{array}$ \\
\hline 1 & Baik & 10 & 32 \\
\hline 2 & $\begin{array}{l}\text { Cukup } \\
\text { baik }\end{array}$ & 21 & 68 \\
\hline 3 & $\begin{array}{l}\text { Kurang } \\
\text { baik }\end{array}$ & $\mathbf{0}$ & $\mathbf{0}$ \\
\hline & Jumlah & 31 & 100 \\
\hline
\end{tabular}

Berdasarkan data pada tabel di atas dapat diketahui bahwa sebagian besar mempunyai Lingkungan yang cukup baik di Dusun
Krajan Lor Dea Rambigundam sebanyak 21 responden $(68 \%)$.

Data Khusus ISPA

Distribusi Frekuensi Responden Berdasarkan Riwayat ISPA di Desa Tarum Kecamatan Prajekan Bondowoso.

\begin{tabular}{|l|l|c|c|}
\hline $\begin{array}{l}\text { N } \\
\text { o }\end{array}$ & $\begin{array}{l}\text { Riwayat } \\
\text { ISPA }\end{array}$ & $\begin{array}{l}\text { Frekuens } \\
\text { i(f) }\end{array}$ & $\begin{array}{l}\text { Prosentase( } \\
\text { \%) }\end{array}$ \\
\hline 1 & $\begin{array}{l}\text { Mengala } \\
\text { mi }\end{array}$ & 22 & 71 \\
2 & $\begin{array}{l}\text { Tidak } \\
\text { Mengala } \\
\text { mi }\end{array}$ & 9 & 29 \\
\hline \multicolumn{2}{|c|}{ Jumlah } & 31 & 100 \\
\hline
\end{tabular}

Berdasarkan data pada label di atas dapat diketahui bahwa sebagian besar responden yang mempunyai riwayat ISPA di Desa Tarum Kecamatan Prajekan Bondowoso sebanyak 22 responden $(71 \%)$

Hubungan Pemberian kapsul Vit ADengan Kejadian ISPA pada Balita di Desa Tarum Kecamatan Prajekan Bondowoso.

\begin{tabular}{|c|c|c|c|c|c|c|}
\hline \multirow{3}{*}{$\begin{array}{l}\text { Fakt } \\
\text { or } \\
\text { Ling } \\
\text { kung } \\
\text { an }\end{array}$} & \multicolumn{4}{|c|}{$\begin{array}{l}\text { ISP } \\
\text { A }\end{array}$} & \multirow{2}{*}{\multicolumn{2}{|c|}{$\begin{array}{l}\text { Ju } \\
\text { ml } \\
\text { ah }\end{array}$}} \\
\hline & \multicolumn{2}{|r|}{$\begin{array}{l}\text { Men } \\
\text { gala } \\
\text { mi }\end{array}$} & \multicolumn{2}{|c|}{$\begin{array}{l}\text { Ti } \\
\text { da } \\
\mathbf{k} \\
\mathbf{M} \\
\text { en } \\
\text { ga } \\
\text { la } \\
\text { mi }\end{array}$} & & \\
\hline & $\mathrm{f}$ & $\%$ & $\mathrm{~F}$ & $\%$ & $\mathrm{~F}$ & $\%$ \\
\hline $\begin{array}{l}\text { Kura } \\
\text { ng } \\
\text { baik }\end{array}$ & 0 & 0 & 0 & 0 & 0 & 0 \\
\hline
\end{tabular}




\begin{tabular}{|l|c|c|c|c|c|c|}
\hline $\begin{array}{l}\text { Cuku } \\
\text { p } \\
\text { baik }\end{array}$ & 14 & 67 & 7 & 33 & 21 & 100 \\
\hline Baik & 8 & 80 & 2 & 20 & 10 & 100 \\
\hline $\begin{array}{l}\text { Juml } \\
\text { ah }\end{array}$ & 22 & 71 & 9 & 29 & 31 & 100 \\
\hline \multicolumn{5}{|c|}{$\begin{array}{c}\text { P } \\
\text { value } \\
=0,0 \\
00\end{array}$} \\
\end{tabular}

Berdadarkan tabel pada di aatas bahwa responden yang mempunyai penilaian lingkungan cukup bak di Desa Tarum Kecamatan Prajekan Bondowoso sebanyak 21 responden sedangkan yang mengalami ISPA sebanyak 22 responden.

\section{Analisa Data}

Berdasarkan hasil uji analisa data dengan menggunakan uji unicoxon diperoleh hasil Pvalue=0,000 @=0,05 sehingga disimpulkan H1 diterima,artinya ada hubungan pemberian kapsul Vit Adengan keadian ISPA.

\section{Pembahasan}

Dapat diketahui bahwa sebagian responden memiliki Kesadaran alam pemberian kapsul Vit A yang cukup baik Desa Tarum Kecamatan Prajekan Bondowoso sebanyak 21 responden $(68 \%)$.

Menurut (Almatsier,2010) Vitamin adalah zat-zat organik komleks yang dibutuhkan dalam jumlah sangat kecil dan pada umumnya tidak dapat dibentuk oleh tubuh. Oleh karna itu, haruz didatangkan dari makanan. Vitamin termasuk kelompok zat pengatur pertumbuhan dan pemeliharaan kehidupan. Tiap Vitamin mempunyai tugas spesifik di dalam tubuh. Karena vitamin adalah zat organik maka vitamin dapat rusak karena penyimpanan dan pengolahan.

Bentuk aktif vitamin A hanya terdapat dalam pangan hewani. Pangan nabati mengandung karotenoid yang merupakan prekursor (provitamin) vitamin A. Diantara ratusan kartenoid yang terdapat di alam, hanya bentuk alfa beta, dan gama serta kriptosantin yang berperan sebagai povitamin A. Beton-kareton adalah bentuk provitamin A paling aktif, yang terdiri atas dua molekol retinol yang saling berkaitan. Karotenoid terdapat di dalam kroplas tanaman dan berperan sebagai katalisator dalam foto sintesis yang dilakukan oleh klorofil. Oleh karna itu, karotinoid paling banyak terdapat dalam sayuran berwarna hijau tua.

Vitamin A yang didalam makanan sebagian besar terdapat dalam bentuk ester retinil, bersama karotenoid bercampur dengan lipida lain di dalam lambung. Di dalam sel-sel mukosa usus halus, ester retinil di hidralisis oleh enzim-enzim pangkreas esterase menjadi retinol ruang lebih efisien diarbsopsi daripada ester retinil. Sebagian dari karotenoid, terutama beta-karoten di dalam sitoplasma sel mukosa usus halus dipecah menjadi retinol.

Retinol di dalam mukosa usus halus bereaksi dengan asam lemak dan membentuk ester dan dengan bantuan cairan empedu menyebrangi sel-sel vili dinding usus halus untuk kemudian diangkut oleh kilomikron melalui sistem limfe ke dalam aliran darah menuju hati.dengan konsumsi lemak yang cukup, sekitar $80-90 \%$ ester retinil dan hanya 40-60\% karotenoid yang diarbsorbsi. Hati berperan sebagai tempat penyimpanan vitamin utama di dalam tubuh. Dalam keadaan normal, cadangan vitamin A dalam hati dapat bertahan hingga enam bulan. Bila tubuh mengalami kekurangan konsumsi vitamin $\mathrm{A}$, asam retinoat diabsorbsi tanpa perubahan. Asam retinoat merupakan sebagian kecil vitamin A dalam darah yang aktif dalam deferesiansi sel dan pertumbuhan.

Bila tubuh memerlukan, vitamin A di mobilisasi dari hati dala bentuk retinol yang diangkut oleh Retinol binding- 
protein (RBP) yang disintesis didalam hati. Pengambilan retinol oleh berbagai sel tubuh bergantung pada reseptor pada permukaan membran yang pesifik untuk RBP. Retinol kemudian di angkut melalui membran sel untuk kemudian diangkat melalui membran sel untuk kemudian diikatkan pada Cellular Retinol Binding-Protein (CRBP) dan RBP kemudian dilepaskan . Di dalam sel mata retinol berfungsi sebagai retinal dandi dalam sel epitel sebagai asam retinoat.

Kurang lebih sepertiga dari karotenoid dalam makanan diubah menjadi vitamin A. Sebagian dari karotinoid diabsorpsi tanpa mengalami perubahan dan masuk ke dalam peredaran darah dalam bentuk karoten. Sebanyak 15-30\% karetenoid di dalam darah adalah beta-kareton, selebihnya adalah karotenoid nonvitamin. Karotenoid ini diangkut di dalam darah oleh berbagai bentuk lipoprotein. Karotenoid disimpan di dalam jaringan lemak dan kelenjar adrenal.

Konsentrasi vitamin A di dalam hati yang merupakan $90 \% \%$ dari simpanan di dalam tubuh mencerminkan konsumsi vitamin tersebut dari makanan. Berdasarkan tabel di atas dapat diketahui bahwa sebagian besar responden yang mengalami riwayat ISPA sebanyak 22 responden( $71 \%)$.

ISPA adalah penyakit yang menyerang salah satu bagian atau lebih saluran nafas mulai hidung (saluran atas) hingga alveoli(saluran bawah)termasuk jaringan adneksanya,seperti sinus,rongga telinga dan pleura.ISPA umunya berlangsung selama 14 hari .yang termasuk dalam infeksi saluran nafas bagian atas adalah batuk pilek sinusitis.sedangkan infeksi yang menyerang bagian bawah saluran nafas seperti paru itu salah satunya adalah pneumonia.(WHO)ISPA (infeksi pernafasan akut)adalah infeksi akut saluran pernafasan bagian atas dan saluran pernafasan bagian bawah beserta adneksanya(Deskes RI,1993)ISPA adalah suatu penyakit yang terbanyak diderita oleh anak anak ,baik dinegara berkembang maupun di negara maju dan sudah mampu dan banyak dari mereka yang perlu masuk rumah sakit karena penyakitnya cukukp gawat.penyakit penyakit saluran pernafasan pada masa bayi dan anak anak dapat pula memberi kecacatan sampai pada masa dewasa(Suprajitno,2004)

\section{Hubungan Pemberian kapsul Vit A Dengan Kejadian ISPA Pada Balita Di Dusun Krajan Lor Desa Rambi gundam}

Berdasarkan tabel di atas bahwa responden yang mempunyai penilaian lingkungan cukup baik sebanyak 21 responden sedangkan yang mengalami ISPA sebanyak 22 responden.Lingkungan adalah kombinasi antara kondisi fisik yang mencakup keadaan sumber daya alam seperti tanah,air,energi,surya,mineral,serta flora dan fauna yang tumbuh di atas tanah maupun di dalam lautan,dengan kelembagaan yang meliputi ciptaan manusia seperti keputusan bagaimana menggunakan lingkungan fisik tersebut.banyak faktor yang mempengaruhi kejadian penyakit ISPA ,baik secara langsung maupun tidak lansung .menurut Sutrisna(1993)faktor risiko yang menyebabkan ISPA pada balita adalah dari faktor lingkungan,sedangkan menurut Depkes RI ,2002,faktor penyebab ISPA adalah balita dengan berat badan lahir rendah(BBLR),status gizi buruk,imunisasi tidak lengkap,kepadatan tempat tinggal dan lingkungan fisik.

Pemberian kapsul Vit A sangat mempengaruhi kejadian ISPA pada balita,hal tersebut dikarenakan sebagian responden banyak yang tidak memperhatikan pentingnya pemberian kapsul Vit A sehingga dapat mempengaruhi kesehatan terutama pada balita yang akan mengakibatkan terjadinya ISPA.

\section{Kesimpulan}

Berdasarkan hasil penelitian dan pembahasan yang telah dilakukan maka dapat di simpukan bahwa pemberian 
kapsul Vit A sangat berhubungan erat dengan kejadian ISPA sebagai berikut:

Pemberian kapsul Vit Adi Desa Tarum Kecamatan Prajekan Bondowoso sebagian besar cukup baik sebanyak 21 responden $(68 \%)$

Kejadian ISPA pada balita di di Desa Tarum Kecamatan Prajekan Bondowoso sebagian besar mengalami ISPA sebanyak 22 responden $(71 \%)$

Ada hubungan Pemberian kapsul Vit A dengan kejadian ISPA di Desa Tarum Kecamatan Prajekan Bondowoso

\section{DAFTAR PUSTAKA}

Ahmadi, UF. 2012. Manajemen penyakit berbasis wilayah, Jakarta : Rajawali Pres.

Arikunto, S, 2002. Prosedur Penelitian : Suatu Pendekatan Praktek, Jakarta : Raneka Cipt.

Arikunto, 2006. Prosedur Peneliaan Suatu Pendekatan Praktek, Jakarta: Salemba Medika.

Candra, Budiman, 2005. Pengantar Kesehatan Lingkungan, Jakarta : EGC.

Rahmawati, dwi dkk . 2012. ISPA Ganguan Pernafasan pada Anak Panduan Tenaga Kesehatan dan Umum, Yogyakarta ; Nuha Medika.

Departemen kesehatan RI, 1991. Pedoman Pemberantasan Penyakit Infeksi Saluran Pernafasan Akut Untuk Penaggulangan Pneumonia Pada Balita: Jakarta.

Departemen Kesehatan RI, 1991. Pedoman Kerja puskesmas, jilid 1, edisi 1991/1992, Jakarta.

Departemen kesehatan RI, 2005. Penanggulangan Pneumonia Balita

Depkes RI .2000, Pedoman Pemberantasn Penyakit ISPA.
Fathonah, S. 2005. Hygiene Dan Sanitasi Makanan. Semarang: Universitas Negeri Semarang Pres.

Mulia, R.M. 2005. Kesehatan lingkungan. Yogyakarta: Graha Ilmu.

Notoatmodjo, soekidjo, 2007. Kesehatan Masyakat Ilmu Dan Seni. Jakarta : PT. Renika Cipta, Jakarta.

Nursalam, 2011. Konsep dan Penerapan Metodologi Penerapan Ilmu Keperawatan Pedoman Skripsi, Tesis, dan Instrumen Penelitian Keperawatan. Jakarta : Salemba Medika.

Sugiono, 2011. Metode Penelitian Kuantitatif,Kualitatif Dan $R \quad \& D$. Bandung : Alfabeta.

Slamet, JS. 2002. Kesehatan Lingkungan. Yogyakarta : Gajah Mada University. 